\title{
Empirijska verifikacija tipologije ateizma
}

\author{
Benjamin ČULIG, Ksenija KLASNIĆ \\ Odsjek za sociologiju Filozofskog fakulteta Sveučilišta u Zagrebu \\ bculig@ffzg.hr,kklasnic@ffzg.hr \\ Jelena JAKŠıĆ \\ Zagreb
}

\begin{abstract}
Temeljna ideja ovog rada jest da se ateističko uvjerenje - na sličan način kao i religijsko - može pojaviti u različitim oblicima i klasificirati na različite načine. U tu svrhu pokušalo se empirijski provjeriti hipotezu o postojanju sedam različitih tipova ateističkog uvjerenja. Tijekom 2008. godine provedeno je preliminarno znanstveno istraživanje metodom ankete na stratificiranome proporcionalnom kvotnom uzorku $(\mathrm{N}=353)$ studenata i studentica Sveučilišta u Zagrebu. Istraživanje je pokazalo da je moguće govoriti o pet tipova ateista: racionalist, pozitivist, antiteist, sudbinist i štovatelj Više sile. Ateist racionalist apsolutno je siguran u nepostojanje Boga te smatra da je religija skup besmislenih postavki i logičkih nedosljednosti. Ateist pozitivist slijepo vjeruje u znanost i drži da će znanost jednog dana objasniti smisao svega postojećeg. Antireligijski orijentiran ateist ili antiteist nije zainteresiran za spoznajna pitanja, kao ni za pitanja smisla postojećeg; njega zanima društveno okruženje. On se obično druži s ateistima, smatrajući ih inteligentnijima od vjernika. Ateist sudbinist nije ni klasičan ateist niti je vjernik. Umjesto vjere u Boga on vjeruje u sudbinu, a objašnjenje svega što mu se događa traži u horoskopima i sličnim alternativnim izvorima objašnjenja vlastitog života i života ljudi oko sebe. Štovatelj Više sile spoznajni je relativist, koji vjeruje u postojanje Više sile. Zaključak je da je jedini "pravi« tip ateista ateist racionalist, dok su svi ostali samo različiti tipovi alternativnog uvjerenja, po strukturi analogni religijskom uvjerenju.
\end{abstract}

Ključne riječi: ateizam, tipovi ateista, ateist racionalist, ateist pozitivist, antiteist, ateist sudbinist, ateist štovatelj Više sile 
... govoriti o religiji znači govoriti o drami suvremenog društva i čovjeka, koja se ne odigrava manifestno, nego latentno, u dubini središnjih struktura suvremenog društva, u unutarnjoj drami mnogoznačnog formiranja čovjekove ličnosti...

(Ćimić, 1984: 10)

\section{Prolog}

U vrijeme kada je Esad Ćimić, jedan od klasika na našim prostorima tada još nepostojeće sociologije religije i religioznosti, objavio svoju Dramu ateizacije, malo je tko mogao pretpostaviti da će ta tema gotovo tri desetljeća kasnije biti ponovno aktualna, ali s obratnim predznakom pa i konotacijom. Iako je riječ o »vječnoj« temi kojom su prožete sve bivše i postojeće civilizacije, začuđuje činjenica da se povijesni preokret događa u gotovo sličnim društvenim okolnostima, ali s obratnom vrijednosnom i ideološkom konotacijom. Kao što je u vrijeme objave Drame ateizacije u Hrvatskoj bilo društveno poželjno smatrati se ateistom, tako je danas - početkom 21. stoljeća - društveno poželjno smatrati se vjernikom. Stoga je odabrani Ćimićev citat ponovno aktualan, $\mathrm{s}$ tom razlikom što se $\mathrm{u}$ današnjem hrvatskom društvu, kao uostalom i mnogim drugim društvima, odigrava »drama« teizacije pa se navedena parafraza čini više nego umjesnom. Ipak, čini se da između ovih dviju »drama« postoji ključna razlika. Naime, početkom osamdesetih godina 20. stoljeća na prostorima bivše SFRJ biti vjernikom bilo je mnogo »opasnije«, nego što je to danas (barem za sad) biti ateistom.

\section{Uvod}

U sociološkim istraživanjima mnogo se češće istražuje fenomen religije i religioznosti negoli fenomen ateizma. ${ }^{1}$ Kao i pri određivanju mnogih kompleksnih socioloških fenomena, tako i pri određivanju fenomena ateizma pronalazimo brojne definicije i klasifikacije. No, čini se da su mnogo češće zastupljene neutemeljene koncepcije, predrasude, mitovi i zablude. Primjerice, Cline (2009) u svojem vodiču o agnosticizmu i ateizmu izjavljuje kako »[n]ikad jedan tako jednostavan koncept nije izazvao toliko dezinformacija, mitova i netrpeljivosti«. »Ideja da Bog ne postoji dugo je zaokupljala ljudski um i maštu, nudeći intelektualno oslobođenje i duhovnu inspiraciju generacijama koje su sebe vidjele zarobljenima, psihički i često (mora se reći) fizički, religijskom prošlošću« (McGrath, 2004: XII). Kroz povijest

\footnotetext{
${ }^{1}$ Istina, sve je više publikacija koje se objavljuju širom svijeta u kojima najčešće poznati intelektualci brane ideju ateizma. No, čini se da je radova na tu temu koji su znanstvene provenijencije, posebice empirijskih, prilično malo.
} 
ljudskog roda, biti ateistom dugo se smatralo nečim nečasnim. Takve se pojedince nerijetko izopćavalo iz društva, označavalo ih se nemoralnima te se smatralo da nisu u stanju voditi potpuno ispunjen život. Nasuprot to$\mathrm{mu}$, vjernicima su se a priori pridavali atributi dobre, moralne i ispunjene osobe.

U suvremenom svijetu već dulje vrijeme prevladava ideja slobode mišljenja. Svjedoci smo, kako zapaža Jukić (1991), dvaju istodobnih, iako nejednako rasprostranjenih procesa: sve jače sekularizacije, ali i sve većeg zanimanja za religiozno. Zrinščak se pita znači li fenomen revitalizacije religije "prolaznu posrnulost sekularističkog trenda« (Zrinščak, 1993: 66) ili ograničenost koncepta sekularizacije. Na populaciji studenata Hrvatske utvrđeno je djelovanje procesa sekularizacije u smislu fragmentiranosti studentske religioznosti, ali istodobno su utvrđeni i značajni kontrasekularizacijski procesi vidljivi u povratku tradicionalnoj i crkvenoj religioznosti (Lažnjak, 1995). Istraživanja također pokazuju da su mladi najnestabilnija kategorija s obzirom na odnos spram religioznosti (Marinović Jerolimov, 1993; Zrinščak, 2001).

Treba spomenuti da novija istraživanja religioznosti pokazuju kako mnogi deklarirani vjernici zapravo baš i ne prihvaćaju temeljne postavke svoje vjere (Črpić i Kušar, 1998; Marinović Jerolimov, 1999, 2005; Maldini, 2006; Klasnić, 2007) te kako je među vjernicima utvrđen »raskorak između visoke konfesionalne identifikacije, nešto manje religijske identifikacije, još manje rasprostranjenosti prihvaćanja temeljnih crkvenih vjerovanja (osim vjere u Boga), te znatno manje rasprostranjenosti osobne religijske prakse « (Marinović Jerolimov, 2005: 331). Istraživanja također pokazuju kako su »[g]rađani starije životne dobi (66 godina i više) skloniji [...] 'religioznosti u skladu s crkvenim učenjem', a oni srednjih godina i mlađi (45 godina i manje) skloniji su 'religioznosti na svoj način'" (Nikodem, 2011: 16). Usprkos tomu, kako navodi Smith u knjizi Atheism: The Case against God, ateizam je, čak i u današnjoj liberaliziranoj društvenoj atmosferi, još uvijek poprilično neprihvatljiv. »[B]iti ateistom može biti prihvatljivo ukoliko to, po mogućnosti, zadržite za sebe« (Smith, 1989: 4).

Prema nekim istraživačima religije i religioznosti (Plačko, 1993) od vremena Drame ateizacije na planu religije i religioznosti dogodile su se znatne promjene koje su postale fenomen vrijedan ozbiljnih znanstvenih istraživanja i kontinuiranog praćenja. Grumelli (prema Ćimić, 1984) je još 1969. godine primijetio kako se ateizam razvija kao integralni dio kulture koja je u svojim temeljima još uvijek teistička, religiozna. U skladu s time i Ćimić zaključuje: »Prebivajući u dnu kolektivne društvene svijesti, ateizam se pojavio zahvaljujući znanstvenoj i tehnološkoj revoluciji, sve većoj 
racionalizaciji života i duhovnoj klimi pluralizma« (Ćimić, 1984: 61). Isti je autor procijenio da su ondašnje generacije mladih, njihova religioznost, odnosno njihov ateizam znatno drukčiji i sadržavaju više dimenzija nego u prijašnjim vremenima. U prilog tomu, treba napomenuti da se i prije Ćimićeve knjige pojavio izvjestan broj autora koji su branili tezu o postojanju bitno različitih tipova vjernika. Tako su primjerice Gorlow i Schroeder (1968) među prvima provjerili hipotezu o postojanju tipologije vjernika s obzirom na motive sudjelovanja u religijskim aktivnostima i utvrdili postojanje sedam tipova vjernika.

Njihova nam je klasifikacija dala ideju o mogućoj tipologiji ateista. Baš kao što religioznost rezultira različitim tipovima vjernika, smatrali smo da i ateizam kao osobno uvjerenje može rezultirati različitim stavovima i načinima percipiranja filozofsko-teoloških pitanja. To nas je potaknulo na provjeru hipoteze o postojanju tipova ateista što je rezultiralo svojevrsnim preliminarnim znanstvenim istraživanjem provedenim na uzorku studenata Sveučilišta u Zagrebu.

U tekstu koji slijedi elaborirat ćemo epistemološke, logičke i psihosocijalne postavke na temelju kojih smo kreirali tipologiju ateista. Dobivena konceptualna tipologija poslužila je kao predložak za operacionalno određenje instrumentarija koji je u istraživanju bio podvrgnut empirijskoj provjeri. Namjera nam je bila provjeriti konstruiranu tipologiju i povezati ju s odabranim stavovskim i sociokulturnim karakteristikama ispitanika.

\section{Pregled definicija i teorijskih postavki o ateizmu i ateistima}

Iako je u Hrvatskoj empirijskih istraživanja na temu ateizma malo, ${ }^{2}$ ateizam kao tema predmet je brojnih radova, kako teorijski utemeljenih, tako i onih znanstveno popularnih, odnosno publicističkih. U tim se radovima prvenstveno i podjednako često polemizira na temu odnosa ateizma i religije. Neki se autori bave i pokušajem klasificiranja ateizma, odnosno ateista. Uvidom u literaturu obiju provenijencija, izdvojili smo ključne definicije, autore i njihove koncepte koji su po našem mišljenju dovoljno plauzibilni i dopuštaju formiranje svojevrsne idealnotipske klasifikacije ateista, odnosno ateizma.

Iako je na prvi pogled značenje pojma »ateizam« većini intuitivno jasno, pri gotovo svakom pokušaju smislenog određenja ateizma otvara se sljedeća dvojba: je li riječ o pukom odbacivanju pojma Boga kao - ra-

\footnotetext{
${ }^{2}$ U Hrvatskoj su još šezdesetih i sedamdesetih godina 20. stoljeća provedena dva velika istraživanja religioznosti i ateizma, oba u sklopu IDIS-a (prvo je provedeno 1969. voditeljice Š. Bahtijarević, a drugo 1972. voditelja Š. Bahtijarević i S. Vrcana).
} 
cionalno gledano - svojevrsnoj besmislici ili je možda riječ o sklonosti vjerovanju da Bog ne postoji? Naime, ako netko vjeruje da Bog ne postoji, on to može iskazati s nekim stupnjem uvjerenja, dok onaj prvi a priori odbacuje mogućnost postojanja Boga. Dakle, »nevjerovanje u Boga« je dihotomno (možete jednostavno vjerovati ili ne vjerovati), dok je u drugom slučaju netko uvjereniji da Bog postoji nego da ne postoji. U skladu s upravo rečenim, smatrat ćemo da postoje »čisti ateisti« kao što postoje i »čisti vjernici«, ali da također postoje i drugi tipovi ateista, kao što postoje i drugi tipovi vjernika. Prije nego što odredimo moguću klasifikaciju, osvrnut ćemo se na neke recentnije radove i izvore koji problematiziraju temu našeg rada.

Prema Dugandžiji (1994) moguće je razlikovati nevjerovanje, nereligioznost i ateizam. $U$ tom smislu nevjerovanje ima najšire značenje, dok je nereligioznost dio nevjerovanja, a ateizam samo jedan oblik nereligioznosti. Dakle, riječ je o supsumiranim pojmovima gdje je ateizam - konotacijski gledano - najužeg opsega. U tom smislu, ateist je osoba koja smatra da nema Boga ili jednostavno odbija teističke pozicije. U širem smislu ateizam je nevjerovanje u Boga, dok u užem smislu označava vjerovanje da nema Boga (Dugandžija, 1994). Distinkcija između vjerovanja da Bog ne postoji i nevjerovanja u Boga predstavlja dva različita shvaćanja ateizma koja se često karakteriziraju kao pozitivni ateizam (vjerovanje u nepostojanje Boga) i negativni ateizam (odsutnost vjerovanja u postojanje Boga) (Routledge Encyclopedia of Philosophy, 1998). Iako nam se spomenuta distinkcija čini plauzibilnom, ostaje nejasnim sljedeće: a) zašto se vjerovanje u nepostojanje Boga naziva pozitivnim ateizmom kad je riječ o vjerovanju; b) može li ateizam po prethodnom određenju biti najuži od triju supsumiranih konotacijskih krugova, a da istodobno čini dihotomiju?

U The Encyclopedia of Philosophy (Edwards, 1967) ateista se definira kao osobu koja drži da nema Boga, da on ne postoji. Navode se dva osnovna tradicionalna ateistička argumenta: vječnost tvari i zlo u svijetu. Argument o vječnosti tvari temelji se na vječnosti i beskonačnosti materija, što znanost može dokazati i time isključiti mogućnost postojanja Boga kao kreatora materije. Drugi argument temelji se na činjenici da u svijetu postoji zlo i različite nesavršenosti, što je u proturječju s postojanjem savršenog Boga.

U Filozofijskom rječniku (Filipović, 1965) ateizam se definira kao poricanje postojanja Boga ili bogova. Prema njemu postoji nekoliko tipova ateizma. Primitivni ateizam možemo pronaći kod nekih plemena i naroda koji uopće nemaju pojam Boga. Za razliku od njega, praktični ateizam odnosi se na ljude koji žive i djeluju kao da Boga nema, oni se ne brinu za 
to postoji li Bog ili ne, iako bi se možda teoretski složili da On ili neko Više biće postoji. Teorijski (dogmatski ili kritički) ateizam je kritički-radikalno i argumentirano nastojanje da se kroz pobijanje teologijskih dokaza za egzistenciju Boga dokaže i pokaže sama nemogućnost Božje egzistencije. Pravi je ateizam isključivo unutar teorijske (racionalističke) sfere. Jedno od mogućih određenja (Anić, 2007) podrazumijeva da je ateizam svjesno odricanje od religije i vjerovanja koja iz nje proizlaze, bezboštvo, ali također i da se objašnjenje ukupnoga materijalnog i duhovnog svijeta može dati bez uvođenja nadnaravnog bića, odnosno da shvaćanje i objašnjenje svijeta može biti znanstveno.

Za razliku od ovog određenja, u kojem je naglašeno svjesno odbacivanje religije, Smith (1989) govori o dvjema širokim kategorijama ateizma te objašnjava razliku između implicitnog i eksplicitnog ateizma. Implicitni ateizam po njemu je nepostojanje teističkih vjerovanja bez svjesnog odbacivanja tih vjerovanja; to je uvjerenje koje ne zahtjeva prethodno poznavanje ideje o postojanju Boga. Ova se vrsta ateizma odnosi na ljude koji uopće nisu bili izloženi teističkim idejama poput, primjerice, novorođenčadi, jer se čovjek »ne rađa s urođenim znanjem o nadnaravnom « (Smith, 1989: 13), potom na ljude koji nemaju kognitivni kapacitet za spoznaju pojma Boga ili jednostavno zbog nekog drugog razloga s tim nisu upoznati. Ova se kategorija također odnosi i na ljude koji su upoznati s teističkim uvjerenjima, ali ih nisu prihvatili. Kod njih zapravo ne postoji eksplicitno odbacivanja vjere u Boga. »[T]akva osoba može biti neodlučna ili indiferentna, no ostaje činjenica da ona ne vjeruje u boga. Dakle, ona je također implicitni ateist « (Smith, 1989: 14). Smith napominje kako je ta vrsta ateizma često konvencionalno ignorirana od strane onih teista koji na ateizam gledaju kao na pozitivno uvjerenje, umjesto kao na nepostojanje uvjerenja. »Teizam se mora naučiti i usvojiti. Ako teizam nije nikad naučen, ne može biti ni prihvaćen - a čovjek ostaje implicitni ateist. Ako je teizam naučen, ali usprkos tome odbačen, čovjek je eksplicitni ateist « (Smith, 1989: 14). Za razliku od implicitnog, eksplicitni ateizam odnosi se na nepostojanje teističkih vjerovanja kao posljedice njihova svjesnog odbijanja. To odbacivanje pretpostavlja upoznatost $\mathrm{s}$ teističkim uvjerenjima, a ponekad se karakterizira kao antiteizam. Mogući su različiti motivi zbog kojih netko može postati eksplicitnim ateistom, od kojih su neki racionalni, a neki nisu.

Prema Smithu, najvažniji oblik eksplicitnog ateizma jest onaj filozofske naravi. Ateist motiviran filozofskim razlozima smatra kako je vjera u Boga iracionalna i stoga je odbacuje. Taj oblik eksplicitnog ateizma počiva na kritici teističkih uvjerenja pa ga prema Smithu treba shvatiti kao kritički ateizam. Takav se ateizam pojavljuje u trima glavnim oblicima koji se mogu opisati 
tvrdnjama (1) " 'Ne vjerujem u postojanje boga ili nadnaravnoga bića'« i (2) " 'Bog ne postoji' ili 'Postojanje boga je nemoguće'« te stavom (3) kojim se »odbija razmatrati postojanje ili nepostojanje boga« jer »je koncept 'boga' nerazumljiv« (Smith, 1989: 15). Razmatranje o implicitnom i eksplicitnom ateizmu Smith zaključuje na sljedeći način: »[...] nedostatak teističkih uvjerenja je srž ateizma. Različite ateističke pozicije razlikuju se samo s obzirom na njihove različite uzroke nevjerovanja (Smith, 1989: 15).

Molnar (1980) u knjizi Theists and Atheists: A Tipology of Non-Belief definira ateizam kao "poricanje bilo kakve nadnaravne moći« (Molnar, 1980: 5). Baveći se tipološkom studijom različitih područja mišljenja o Bogu, dolazi do pet tipova ateizama: panteizam, materijalizam, primitivni humanizam, radikalni humanizam te ultranadnaravni ateizam. Svim je ovim tipovima ateizama zajednička jedna karakteristika: »stavljanje čovjeka na mjesto Boga« (Molnar, 1980: 180).

Grumelli u »Doprinosu tipologiji ateizma« (1970, prema Ćimić, 1984) govori o četirima tipovima ateizma (teorijski ili negativni ateizam, ideološki ili pozitivni ateizam, funkcionalni ateizam te sociološki ateizam), odnosno trima aspektima suvremenog ateizma (aspekt kvalitativne promjene, aspekt dimenzije i aspekt tendencije). Dok se teorijski ili negativni ateizam odnosi na »intelektualno odbijanje i poricanje Boga na temelju filozofskog razmišljanja o biti svega što jest« (Ćimić, 1984: 62), ideološki ili pozitivni ateizam je »teorijsko-praktična negacija Boga koja ga zamjenjuje humanim vrijednostima - ljudskom solidarnošću, odgovornošću« (Ćimić, 1984: 62). Funkcionalni ateizam utemeljen je na funkcionalizmu i pluralizmu, dok je sociološki ateizam »uvjetovan indiferentnošću spram religijskih vrednota« (Ćimić, 1984: 62), on je iskustven, neposredan i otvoren za dijalog. Pod aspektom kvalitativne promjene Grumelli podrazumijeva prerastanje iz negativnog u pozitivni ateizam, aspekt dimenzije odnosi se na širenje ateizma iz društvenih elita na šire društvene slojeve, a aspekt tendencije na činjenicu da ateizam svojim osnaživanjem i urastanjem u sustav društveno-kulturnih vrijednosti potiče religiju da se iznova opravdava.

Prema Ćimiću (1984) ateizam, odnosno ateističko uvjerenje moguće je klasificirati na dva načina. Prvi se način temelji na filozofijsko-epistemološkim pretpostavkama, a drugi predstavlja svojevrsnu psihosocijalnu klasifikaciju. Iako iz Ćimićeve Drame ateizacije nije posve jasno u kakvom su odnosu te dvije klasifikacije, na temelju djelomične sukladnosti nekih tipova iz obiju klasifikacija smatrat ćemo da ih je moguće objediniti i time dobiti tipologiju čiju bismo opstojnost mogli empirijski verificirati.

Dakle, prema Ćimiću, u epistemološkom smislu, postoje četiri temeljna tipa ateista. Estetski ateist u religiji ne nalazi dovoljno mogućnosti za sa- 
morazvitak te mu filozofija i umjetnost postaju svojevrsnom sublimiranom religijom. Znanstveni ateist je osoba koja nema kritički odnos prema znanosti. On vjeruje u znanost pa je to uvjerenje zapravo zamjena za religijsko uvjerenje, odnosno druga vrsta sublimirane religije. Socijalni ateist oslanja se na ideju humanizma i humanizacije u kojoj je čovjek, odnosno individuum glavni akter, a Boga se vidi kao otuđujućeg posrednika. Indiferentni ateist nesklon je dubokoj misli, moralnoj krizi pa i potrebi za spoznavanjem. On, dakle, niti vjeruje u Boga niti ga odbacuje.

Druga klasifikacija po našem je uvjerenju utemeljena na psihosocijalnim motivima od kojih su neki tipovi izravno povezivi s tipovima iz prve klasifikacije, a neki su njezina nadopuna. U tom smislu Ćimić navodi tri tipa ateizma. Incidentni ateizam je izazov čovjeku, a ne religiji, on izvire iz težnje za jeftinim efektima i umirenjem vlastite ateističke savjesti, pri čemu je to uvjerenje tim veće što je veće suprotstavljanje klerikalizmu Crkve. Spontani ateizam zapravo je vrsta indiferentnosti prema religiji koja nastaje spontano tijekom čovjekova razvitka. Osnovno obilježje socijalno osmišljenog ateizma jest integralnost koja vodi stvaranju humane zajednice.

Jedan od najpoznatijih suvremenih zastupnika ateizma svakako je Richard Dawkins. Prema Dawkinsu (2007), s obzirom na stupanj sigurnosti u postojanje/nepostojanje Boga, svaka osoba može biti jednoznačno svrstana na sedmerostupanjskoj skali teizma-ateizma.

Marinović Jerolimov (1993) u radu »Nereligioznost u Hrvatskoj 19681990 « dolazi do zaključka da je nereligiozna orijentacija bila dominantna u 1982. i 1987. godini, a najviša u 1988. godini te da se u 1989/90. godini smanjila. Postotak protivnika religije sustavno je opadao, za razliku od nereligioznih koji nemaju ništa protiv religije. Nereligiozno orijentirani bili su većinom muškarci te ispitanici skloni tadašnjem političkom sustavu, kao i odgovarajućoj ideologiji.

\section{Tipologija ateizma/ateista i ostalih neteističkih uvjerenja ${ }^{3}$}

Temeljem proučene literature konstruirali smo vlastitu tipologiju utemeljenu na stavovima koji nisu teistički (ateistički, antiteistički i agnostički), za koju smo smatrali da ju je moguće empirijski verificirati. Ovu konceptualnu tipologiju sačinjavalo je 7 različitih tipova uvjerenja. Smatrali smo kako je za potrebe ovog istraživanja legitimno različite oblike nevjerovanja u Boga

\footnotetext{
${ }^{3}$ Budući da su nositelji ateističkih uvjerenja ateisti, moguće je simultano govoriti i o tipovima ateizma i o tipovima ateista. U ovom ćemo se radu koristiti obama određenjima, smatrajući ih korespondentnim pojmovima. Dakle, kad je riječ o empirijskoj verifikaciji tipologije ateizma, smatrat ćemo dobivene tipove plauzibilnima upravo stoga što smo pronašli njihove zastupnike (ili protivnike, dakako).
} 
s njihovim različitim epistemološkim, psihosocijalnim, logičkim i drugim utemeljenjima nazivati tipovima ateističkih uvjerenja čiji su nositelji ateisti, a pri tome smo se vodili sljedećom Smithovom mišlju: »Termin 'ateist' govori [...] da netko ne vjeruje u boga, ali nam ne specificira zašto. Bez obzira na uzrok nečijeg nevjerovanja, onaj tko ne vjeruje u boga je ateist « (Smith, 1989: 14). Pod pojmom ateista podrazumijevamo osobu koju karakterizira nepostojanje vjerovanja u postojanje Boga ili bogova (tzv. negativni ateizam), dok pod pojmom agnostika podrazumijevamo osobu koja prihvaća filozofsku poziciju prema kojoj niti uvjerenje o postojanju, niti ono o nepostojanju Boga nije racionalno, jer ljudski razum nije sposoban pružiti racionalno utemeljenje ni za jedno od tih uvjerenja (Routledge Encyclopedia of Philosophy, 1998). Stoga su naši konceptualno pretpostavljeni tipovi bili sljedeći:

- Znanstveni ateist (racionalist, pozitivist, prosvjetitelj, enciklopedist) vjeruje u znanost i znanstveno objašnjenje, smatra da se čovjek razumom može uvjeriti u nepostojanje Boga, da će znanost jednog dana objasniti posljednje istine te nastoji argumentirano opovrgnuti postojanje Boga.

- Etički ateist smatra da prevladavanje zla u svijetu opovrgava postojanje Boga. Smatra kako je povijest puna ratova i stradanja, što Crkva i sama potiče praveći razlike među ljudima, vjerama, nacijama i slično. Ovaj ateist također smatra da čovjek može biti dobar ili loš bez obzira na vjerovanje ili nevjerovanje u Boga.

- Socijalni ateist za bliske prijatelje odabire ateiste, samo se dobro osjeća u njihovu društvu, smatra da su ateisti kvalitetniji ljudi, a vjernike omalovažava smatrajući ih ljudima nižih kognitivnih sposobnosti.

- Kritički ateist ili antiteist prema religiji ima afektivno negativan stav (nerijetko mržnja prema religiji), smatra da su vjernici zaluđena masa, a vjera »opijum za narod « te da se religija suviše miješa u život pojedinca i nerijetko u pojedincima pobuđuje bezrazložan osjećaj krivnje.

- Alternativni ateist ne vjeruje u Boga, ali vjeruje u postojanje Više sile (Viših sila), prepoznaje (osjeća) nadnaravnost i razlikuje objašnjivo od neobjašnjivog, no religija je za njega suviše »antropomorfna«. Smatra da Viša sila (nenametljivo) upravlja našim životima.

- Nezainteresirani ateist uopće se ne zanima za to postoji li Bog ili ne jer smatra kako čovjek može živjeti jednako dobro/loše i bez Boga i bez religije. Ne treba gubiti vrijeme razmišljajući o Bogu i vjeri; religija je za njega dosadna, opterećujuća i zamarajuća, dakle, čovjeku potpuno nepotrebna. 
- Agnostik vjeruje da ni znanost, ni religija nikad neće spoznati posljednje istine, da je uvijek moguće naći jednak broj argumenata i za i protiv postojanja Boga te da - ako i postoji neka Viša sila - to ne mora biti Bog. Pitanje o postojanju Boga transcendira racionalnu spoznaju pa odgovor na to pitanje ne treba biti imperativ.

Multidimenzionalna skala namijenjena mjerenju spomenutih tipova ateista sastojala se od 26 čestica, pri čemu su pojedini indikatori dobiveni operacionalizacijom prethodno prikazane tipologije, a svakoj je čestici pridružena klasična peterostupanjska ordinalna skala slaganja.

\subsection{Tipovi ateista i njihove stavovske karakteristike}

Smatrali smo bitnim ispitati i neke druge stavovske strukture za koje smo pretpostavili da će pridonijeti prepoznavanju i razumijevanju razlika između pojedinih tipova ateista. Kao relevantne koncepte u našem istraživanju pretpostavili smo višestruko provjerene političke koncepte: klerikalizam, nacionalizam, multikulturalizam i europeizam (Čulig, 2004). Klerikalizam je ideja kojom se zagovara veći utjecaj Crkve na politička zbivanja. Klerikalna uvjerenja podrazumijevaju da bi svećenstvo trebalo imati političke predstavnike u Saboru i da bi se zakoni trebali temeljiti na naučavanju Crkve (Čulig, 2004). »Nacionalizam je ideologija koja se orijentira i uspoređuje s 'tuđim'. Stalnim uspoređivanjem on stvara i održava sliku o sebi. Nacionalist mjeri svoju naciju u odnosu prema drugim nacijama i stvara prestiž vlastite nacije; traži natjecanje s nacijama, čije se nadmoći boji i protiv kojih se mora potvrđivati« (Aničić, 2007: 268). Europeizam je ideja o Europi kao jedinstvenom političkom entitetu, bez država i granica, a predstavlja svojevrsnu redukciju ideje kozmopolitizma/mondijalizma (Čulig, 2004). Multikulturalizam se, u pojednostavljenoj definiciji, odnosi na priznavanje »činjenice kulturnoga [...] pluralizma i prava različitih društvenih grupa [...] na zadržavanje svojih kulturnih specifičnosti« (Mesić, 2006: 67).

$\mathrm{U}$ istraživanje smo također uključili neke mjere religijskog identiteta, kao i neke sociodemografske karakteristike ispitanika.

\section{Uzorak, instrumentarij i metode obrade podataka}

Cjelokupno istraživanje provedeno je u prosincu 2008. godine metodom ankete na stratificiranom proporcionalnom kvotnom uzorku $(\mathrm{N}=353)$ studenata i studentica Sveučilišta u Zagrebu u sklopu istraživanja »Sociokulturni i psihosocijalni aspekti religioznosti studenata Sveučilišta u Zagrebu«. ${ }^{4}$

\footnotetext{
${ }^{4}$ Istraživanje je provedeno u okviru kolegija »Istraživački projekt« diplomskog studija sociologije Filozofskog fakulteta u Zagrebu.
} 
Uzorak je stratificiran s obzirom na četiri glavne grupacije fakulteta: društveno-humanističku, tehničku, medicinsku/biotehničku te prirodoslovnu. Podaci su ponderirani s obzirom na grupu fakulteta te godinu studija (više i niže godine studija). Rezultati izneseni u ovom radu odnose se na poduzorak ispitanika koji se nisu izjasnili kao vjernici.

Anketom su provjeravani brojni aspekti religioznosti. Pojedini instrumenti anketnog upitnika konstruirani su i provjeravani u ranijim istraživanjima. ${ }^{5}$ Za potrebe ovog istraživanja instrumenti su u većoj ili manjoj mjeri revidirani, dok su neki konstruirani po prvi put.

$\mathrm{U}$ istraživanju su analizirane sljedeće sociodemografske karakteristike: spol, studijska godina (niže i više godine studija), stupanj obrazovanja oca i majke (do završene srednje škole te viša škola ili više), procjena religioznosti oca i majke trima kategorijama (vjernik/ca ili skloniji/a vjerovanju, ne može procijeniti te ateist/ica ili skloniji/a nevjerovanju) te grupe fakulteta shodno prethodno spomenutom stratificiranju.

Religijski identitet mjerili smo stupnjem uvjerenja (uvjereni ateist, mnogo skloniji nevjerovanju nego vjerovanju, ne znam, ne mogu procijeniti te mnogo skloniji vjerovanju ili uvjereni vjernik), ${ }^{6}$ odnosom prema ateizmu i religijskom uvjerenju (uvjereni protivnik religijskog uvjerenja, donekle protivnik religijskog uvjerenja, nisam protivnik niti ateizma niti religijskog uvjerenja te donekle ili uvjereni protivnik ateizma), ${ }^{7}$ mišljenjem o postojanju Boga (apsolutno sam siguran da Bog ne postoji, skloniji sam mišljenju da Bog ne postoji te skloniji sam mišljenju ili sam apsolutno siguran da Bog postoji), ${ }^{8}$ odnosom prema nauku Crkve (nisam vjernik, sumnjam u temeljne ili prihvaćam samo temeljne postavke vjere te prihvaćam postavke vjere dje-

\footnotetext{
${ }^{5}$ Posljednje istraživanje u kojemu su provjeravani neki instrumenti koji su dio našeg instrumentarija, provedeno je u lipnju 2006. pod nazivom »Psihosocijalni i sociokulturni aspekti religioznosti

${ }^{6}$ Ova je varijabla u originalnom obliku imala pet kategorija: (1) uvjereni ateist, (2) mnogo skloniji nevjerovanju nego vjerovanju, (3) ne znam, ne mogu procijeniti, (4) mnogo skloniji vjerovanju nego nevjerovanju te (5) uvjereni vjernik, ali su zbog vrlo malog broja ispitanika u kategorijama 4 i 5 na analiziranom poduzorku ove dvije kategorije spojene u jednu.

${ }^{7}$ Ova je varijabla također u originalnom obliku imala pet kategorija: (1) uvjereni protivnik religijskog uvjerenja, (2) donekle protivnik religijskog uvjerenja, (3) nisam protivnik ni ateizma ni religijskog uvjerenja, (4) donekle protivnik ateizma te (5) uvjereni protivnik ateizma, ali su ponovno zbog vrlo malog broja ispitanika u kategorijama 4 i 5 na analiziranom poduzorku ove dvije kategorije spojene u jednu.

${ }^{8} \mathrm{U}$ originalnom obliku ova je varijabla imala četiri kategorije: (1) apsolutno sam siguran da Bog ne postoji, (2) skloniji mišljenju da Bog ne postoji, (3) skloniji mišljenju da Bog postoji te (4) apsolutno sam siguran da Bog postoji. Zbog malog broja ispitanika u kategorijama 3 i 4 na analiziranom poduzorku ove su dvije kategorije spojene u jednu.
} 
lomično ili u potpunosti) ${ }^{9}$ te utjecajem na formiranje odnosa prema religiji (obitelj, sredina u kojoj su odrasli, sami su došli do toga, netko drugi).

Instrument namijenjen provjeri tipologije ateista sastojao se od 26 tvrdnji s peterostupanjskom ordinalnom skalom slaganja, s uputom da na sljedeća pitanja odgovaraju samo oni koji se nisu izjasnili kao vjernici.

Nakon provedbe deskriptivne analize, skala tipova ateista podvrgnuta je komponentnoj analizi uz GK kriterij i varimax rotaciju bazične solucije. Instrument za mjerenje političkih koncepata također je faktoriziran, a za transformaciju je korišten oblimin kriterij.

$\mathrm{Na}$ instrumentu za mjerenje tipova ateista provedena je provjera metrijskih karakteristika te »čišćenje« instrumenta isključivanjem iz analize onih varijabli koje nisu zadovoljile Thurstoneov princip jednostavne strukture ili su pak činile faktor specificiteta. Za testiranje razlika u prosjecima između pojedinih grupa korišteni su parametrijski testovi t-test i jednosmjerna analiza varijance. Multipla regresijska analiza provedena je stepwise metodom na zadržanim tipovima ateista kao kriterijskim varijablama i dimenzijama političkih stavova kao prediktorima. Analiza varijance korištena je za utvrđivanje razlike u prosječnom faktorskom skoru na pojedinim dimenzijama tipologije ateista $\mathrm{s}$ obzirom na različite sociodemografske karakteristike ispitanika. Pri provedbi analize varijance i t-testa neke varijable su rekodirane tako da su pojedine grupe ispitanika spojene. Sve hipoteze testirane su na razini rizika od $5 \%$.

\section{Analiza i interpretacija rezultata}

Poduzorak $(\mathrm{N}=87)$ ispitanika koji su ispunili instrument za mjerenje tipova ateizma činio je $30 \%$ svih anketiranih ispitanika, a sastojao se od 56 studenata (32\% svih studenata u uzorku) i 32 studentice (18\% svih studentica u uzorku). U analiziranom poduzorku bilo je $38,1 \%$ ispitanika s tehničkih, $36,4 \% \mathrm{~s}$ društveno-humanističkih, $13,8 \% \mathrm{~s}$ medicinskih i biotehničkih te $11,7 \%$ s prirodoslovnih fakulteta. Ovaj se uzorak statistički značajno ne razlikuje od strukture ukupnog uzorka $\left(\chi^{2}=3,649\right.$; $d f=3$; $\left.p=0,302\right)$. Nadalje, $63 \%$ ispitanika je s nižih godina studija. U poduzorku $59 \%$ ispitanika ima visoko obrazovanog oca, a 56\% visoko obrazovanu majku.

Više od $50 \%$ ovih ispitanika izjavljuje da im je otac ateist ili skloniji nevjerovanju, dok $50 \%$ njih procijenjuje da im je majka vjernica ili

\footnotetext{
${ }^{9} \mathrm{U}$ originalnom obliku ova je varijabla imala šest kategorija: (0) nisam vjernik, (1) muči me sumnja i u neke od temeljnih postavki vjere, (2) prihvaćam samo temeljna učenja vjere, (3) prihvaćam crkveni nauk, ali se s dosta toga ne slažem, (4) prihvaćam crkveni nauk, iako se s ponekim dijelovima ne slažem te (5) u potpunosti prihvaćam sve što naučava moja Crkva. Za potrebe analize na ovom poduzorku spojene su kategorije 1 i 2 te 3,4 i 5 .
} 
sklonija vjerovanju. Zanimljivi su podaci dobiveni mjerenjem religijskog identiteta. Naime, s obzirom da se na početku instrumenta za mjerenje tipova ateista nalazila uputa ispitanicima da na sljedeća pitanja odgovaraju samo oni koji se nisu izjasnili kao vjernici, očekivali smo njihovo konzistentno izjašnjavanje i na ostala pitanja religijskog identiteta (koja su se u upitniku nalazila prije instrumenta za mjerenje tipova ateista). Pokazalo se, naime, da je uvjerenih ateista »samo« $1 / 4$ ispitanika, dok je najviše onih koji su se izjasnili kao mnogo skloniji nevjerovanju nego vjerovanju (nešto manje od 50\%). Ostavljamo otvorenim pitanje je li ateističko deklariranje svojevrsni tabu. Nadalje, u našem je poduzorku 7\% onih koji su mnogo skloniji vjerovanju, a $17 \%$ njih ne može procijeniti vlastiti stupanj ne/uvjerenja, bilo religijskog bilo ateističkog. Sukladno tome, nešto više od 1/4 ispitanika apsolutno je sigurno da Bog ne postoji, nešto manje od $1 / 2$ su skloniji mišljenju da Bog ne postoji, dok je $1 / 4$ ispitanika sklonija mišljenju ili su čak uvjereni da Bog postoji. Kad je riječ o njihovu odnosu prema ateizmu i religijskom uvjerenju, najveći je broj onih (56\%) koji nisu protivnici ni ateizma, niti religijskog uvjerenja. Nešto više od $1 / 4$ ispitanika izjašnjava se kao djelomični protivnici religijskog uvjerenja, dok se nešto manje od $15 \%$ svrstava u uvjerene protivnike religijskog uvjerenja. $\mathrm{S}$ druge strane, nešto manje od $5 \%$ ispitanika pripada u blaže ili uvjerene protivnike ateizma. ${ }^{10}$

Odnos prema nauku Crkve pokazuje da se više od 2/3 ispitanika svrstava u kategoriju »nisam vjernik«, nešto više od $1 / 4$ njih sumnja i u temeljne postavke vjere ili prihvaća samo temeljne postavke vjere, dok samo $8 \%$ njih djelomično ili u potpunosti prihvaća vjerske postavke Crkve. Napomenimo još kako nas je zanimalo i koji su to akteri, ili »značajni drugi«, za koje naši ispitanici procjenjuju kako su imali najveći utjecaj pri formiranju njihova odnosa prema religiji. Nije neočekivan nalaz da je gotovo polovina njih do svoga trenutačnog odnosa prema religiji došla sama, nešto više od četvrtine izjavljuje kako je njihova obitelj imala na njih najveći utjecaj, $10 \%$ njih procjenjuje kako je njihov trenutačni odnos prema religiji rezultat utjecaja sredine u kojoj su odrasli, dok je za $15 \%$ ispitanika to bio netko drugi (vjerska zajednica, prijatelji, škola $\mathrm{i}$ dr.).

\subsection{Deskripcija instrumenta za mjerenja tipova ateista}

Deskriptivna analiza našega instrumenta pokazala je da je većina varijabli unimodalna i blago desno asimetrična (prosjek pomaknut prema višim

\footnotetext{
${ }^{10}$ Mišljenja smo da je navedena nekolicina ispitanika jednostavno previdjela uputu za rješavanje instrumenta za mjerenje tipova ateista te su ispunili instrument koji njima nije »bio namijenjen«, a moguće je da oni baš i nisu sigurni u svoje uvjerenje.
} 
vrijednostima skale). Pouzdanost skale po Cronbachu $\alpha=0,738$. Tablica 1 prikazuje svih 26 čestica instrumenata te odgovarajuće postotke ispitanika. Prikazani postoci odnose se na ukupan broj valjanih odgovora.

Tablica 1. Instrument za mjerenje tipova ateista: distribucije postotaka odgovora, ukupan broj valjanih podataka za pojedinu varijablu, prosječne vrijednosti pojedinih varijabli na skali 1-5

v1. Nastanak života na Zemlji može se objasniti jedino znanošću.

v2. Ne vjerujem u Boga, ali vjerujem u postojanje Više sile.

$\begin{array}{lllllll}14 \% & 14 \% & 30 \% & 30 \% & 12 \% & 87 & 3,13\end{array}$

v3. Religija je potrebna onima koji se ne mogu sami nositi sa životnim problemima.

$\begin{array}{lllllll}5 \% & 21 \% & 27 \% & 33 \% & 15 \% & 87 & 3,33\end{array}$

v4. Sve svjetske religije pune su logičkih nedosljednosti.

v5. Vjerska netrpeljivost uzrok je većini ratova kroz svjetsku povijest.

v6. Horoskop će jednog dana biti znanstveno prihvaćen.

v7. Da postoji Bog, ne bi bilo toliko zla u svijetu.

v8. Rasprave o postojanju Boga za mene su gubitak vremena.

v9. Čovjek može biti dobar bez obzira na to je li religiozan ili ne.

v10. Za mene osobno religija je skup besmislenih postavki.

$\begin{array}{llllllll}1 \% & 9 \% & 22 \% & 40 \% & 28 \% & 87 & 3,86\end{array}$

$\begin{array}{llllllll}3 \% & 12 \% & 18 \% & 53 \% & 14 \% & 87 & 3,64\end{array}$

$\begin{array}{lllllll}45 \% & 27 \% & 26 \% & 3 \% & 0 \% & 87 & 1,86\end{array}$

$\begin{array}{lllllll}21 \% & 18 \% & 42 \% & 12 \% & 8 \% & 86 & 2,67\end{array}$

$\begin{array}{lllllll}9 \% & 28 \% & 20 \% & 32 \% & 11 \% & 87 & 3,09\end{array}$

$\begin{array}{lllllll}0 \% & 0 \% & 3 \% & 20 \% & 77 \% & 86 & 4,74\end{array}$

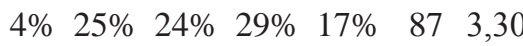

v11. Religija mi je neprihvatljiva prvenstveno zato što se previše miješa u privatni život pojedinca.

v12. Za mene su svi vjernici gomila zaslijepljenih ljudi koji uopće nemaju svoje mišljenje.

$\begin{array}{lllllll}15 \% & 41 \% & 19 \% & 14 \% & 11 \% & 87 & 2,65\end{array}$

v13. Za bliske prijatelje odabirem isključivo ateiste. $\begin{array}{lllllll}62 \% & 24 \% & 13 \% & 1 \% & 0 \% & 87 & 1,54\end{array}$ 
v14. Religioznost čovjeku nimalo ne

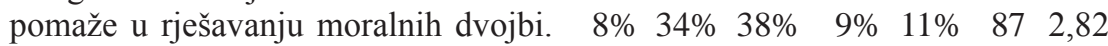

v15. Ne vjerujem u Boga, ali u teškim trenucima osjetim potrebu da mu se na neki način obratim.

$\begin{array}{llllllll}31 \% & 29 \% & 17 \% & 22 \% & 1 \% & 87 & 2,32\end{array}$

v16. Znanost će jednog dana zasigurno doći do odgovora na pitanja o smislu svega postojećeg.

$\begin{array}{lllllll}9 \% & 17 \% & 38 \% & 21 \% & 16 \% & 87 & 3,17\end{array}$

v17. Ako Bog i postoji, to se nikad neće moći dokazati.

$\begin{array}{lllllll}1 \% & 7 \% & 29 \% & 39 \% & 23 \% & 87 & 3,77\end{array}$

v18. Ne isključujem mogućnost postojanja neke Više sile koja upravlja našim životima.

$\begin{array}{lllllll}9 \% & 22 \% & 20 \% & 33 \% & 15 \% & 86 & 3,24\end{array}$

v19. Neka znanost priča što god hoće, ali ljudima su neke stvari naprosto suđene.

$\begin{array}{lllllll}24 \% & 27 \% & 30 \% & 16 \% & 4 \% & 87 & 2,49\end{array}$

v20. Jedino se dobro osjećam u društvu onih koji o Bogu i vjeri misle isto što i ja.

$\begin{array}{lllllll}38 \% & 39 \% & 14 \% & 8 \% & 1 \% & 87 & 1,95\end{array}$

v21. Mene ustvari uopće ne zanimaju rasprave ni o Bogu, ni o religiji.

v22. Smatram da postoje podjednako prihvatljivi argumenti i za i protiv postojanja Boga.

$\begin{array}{lllllll}14 \% & 30 \% & 24 \% & 22 \% & 9 \% & 87 & 2,81\end{array}$

v23. Ništa nije moguće tvrditi s apsolutnom sigurnošću pa tako ni postojanje Boga.

$\begin{array}{llllllll}8 \% & 42 \% & 15 \% & 20 \% & 15 \% & 87 & 2,93\end{array}$

v24. Siguran sam da će paraznanstveni fenomeni, primjerice parapsihološki, jednog dana biti u potpunosti znanstveno objašnjeni.

$\begin{array}{llllllll}3 \% & 11 \% & 33 \% & 40 \% & 12 \% & 86 & 3,47\end{array}$

v25. Ateisti su u pravilu inteligentniji od vjernika.

$\begin{array}{lllllll}23 \% & 27 \% & 27 \% & 18 \% & 5 \% & 86 & 2,56\end{array}$

v26. U teškim trenucima i ja pomislim da Bog možda ipak postoji.

$\begin{array}{lllllll}31 \% & 27 \% & 23 \% & 17 \% & 2 \% & 87 & 2,32\end{array}$

Kao što je vidljivo iz tablice, najveći postotak ispitanika slaže se s tvrdnjama prema kojima čovjek može biti dobar bez obzira na to je li religiozan ili nije (njih 97\%), ${ }^{11} 76 \%$ njih smatra kako ništa nije moguće tvrditi s apsolutnom sigurnošću pa tako ni postojanje Boga, 68\% slaže se

\footnotetext{
${ }^{11}$ Navedeni postoci dobiveni su zbrajanjem postotaka onih ispitanika koji se slažu i onih koji se u potpunosti slažu sa spomenutom tvrdnjom.
} 
s tvrdnjom kako su sve svjetske religije pune logičkih nedosljednosti, $67 \%$ njih smatra kako je vjerska netrpeljivost uzrok većini ratova kroz svjetsku povijest, $64 \%$ njih smatra kako se nastanak života na Zemlji može objasniti samo znanošću, a $62 \%$ ispitanika smatra da ako Bog i postoji, to se nikad neće moći dokazati. Tvrdnja koja se odnosi na odabir bliskih prijatelja pokazuje da sklonost ateizmu uopće ne utječe na odabir prijatelja, jer se tako djelomično ili u potpunosti izjasnilo $86 \%$ ispitanika. Vidimo također da se $77 \%$ ispitanika ne osjeća nužno loše u društvu onih koji vjeruju što sveukupno govori da ateisti ne iskazuju društvenu netrpeljivost prema osobama drukčijeg uvjerenja. Još su zanimljiva dva nalaza: ideja horoskopa kao moguće alternative znanosti u 72\% slučajeva se odbacuje, a samo 19\% obraća se Bogu u teškim trenucima.

\subsection{Faktorska analiza instrumenta za mjerenje tipova ateista}

Na svim česticama novokonstruirane multidimenzionalne skale tipova ateista provedena je odgovarajuća faktorska analiza spomenuta u poglavlju 5. U bazičnoj soluciji ekstrahirano je osam, po GK kriteriju, statistički značajnih latentnih dimenzija koje tumače $68,33 \%$ ukupne varijance instrumenta. Budući da neke varijable nisu zadovoljile Thurstoneov princip jednostavne strukture ili su pak činile faktore specificiteta, isključili smo ih iz daljnje analize. Riječ je sljedećih osam varijabli (Tablica 1): v5, v7, v8, v9, v11, v17, v21, v22.

Uvidom u sadržaj isključenih varijabli, primjećujemo da varijable koje su po pretpostavci trebale mjeriti u teoriji predviđenu dimenziju vezanu uz ratove, povijest i zlo u svijetu, kao i neka temeljna etička pitanja nisu na konzistentan način prihvaćene/odbačene što je razlog da se taj potencijalni tip ateista sadržajno nije formirao kao zasebna dimenzija. Jednako tako, ni varijable namijenjene mjerenju agnostičkog shvaćanja nisu formirale odgovarajući faktor. To zapravo znači da u našem uzorku ne postoje ispitanici koji bi te dimenzije konzistentno prihvaćali, odnosno odbacivali. Napokon, iz analize su također izbačene varijable koje se odnose na nezainteresiranost za raspravu o postojanju Boga, odnosno mišljenje o dokazivosti njegova postojanja. Čini se da etička pitanja za naše ispitanike nisu mjerilo njihova ateističkog uvjerenja. Stoga smo pristupili »čišćenju« dobivene faktorske solucije, nakon čega smo finalnoj soluciji zadržali pet statistički značajnih faktora koji tumače $64,44 \%$ ukupne varijance instrumenta, a interna konzistentnost nove skale s osamnaest zadržanih varijabli iznosila je $\alpha=0,703,{ }^{12}$ što možemo smatrati zadovoljavajućom vrijednošću. U daljnjoj

\footnotetext{
${ }^{12}$ Kao što vidimo, pouzdanost je ostala gotovo ista, što je samo daljnja potkrjepa za korektnost izbacivanja navedenih varijabli.
} 
nas je analizi zanimao odgovor na pitanje koliko je dobivena ortogonalna solucija faktorski »održiva«. Pokušaj proizvođenja kose transformacije koji je proveden uz oblimin kriterij pokazao je da dobivene solucije ne mijenjaju smisao dobivenih dimenzija pa smo smatrali opravdanim pristupiti interpretaciji varimax solucije (Tablica 2).

Tablica 2. Varimax solucija

\begin{tabular}{|c|c|c|c|c|c|}
\hline & \multicolumn{5}{|c|}{ Faktor } \\
\hline & 1 & 2 & 3 & 4 & 5 \\
\hline $\begin{array}{l}\text { Za mene osobno religija je skup besmislenih } \\
\text { postavki. }\end{array}$ & ,847 & & , 149 & & \\
\hline $\begin{array}{l}\text { Religioznost čovjeku nimalo ne pomaže u } \\
\text { rješavanju moralnih dvojbi. }\end{array}$ & ,794 & ,191 & ,127 & ,102 & \\
\hline $\begin{array}{l}\text { Sve svjetske religije pune su logičkih } \\
\text { nedosljednosti. }\end{array}$ & ,614 & ,369 & &,- 174 & ,244 \\
\hline $\begin{array}{l}\text { Ne vjerujem u Boga, ali u teškim trenucima } \\
\text { osjetim potrebu da mu se na neki način } \\
\text { obratim. }\end{array}$ &,- 534 & ,224 & , 166 &, 525 & ,278 \\
\hline $\begin{array}{l}\text { Za mene su svi vjernici gomila zaslijepljenih } \\
\text { ljudi koji uopće nemaju svoje mišljenje. }\end{array}$ & ,465 & ,294 & ,402 & & ,375 \\
\hline $\begin{array}{l}\text { Znanost će jednog dana zasigurno doći do } \\
\text { odgovora na pitanja o smislu svega postojećeg. }\end{array}$ & ,145 & ,766 & & ,163 & \\
\hline $\begin{array}{l}\text { Siguran sam da će neki neobjašnjivi fenomeni } \\
\text { (primjerice parapsihološki) jednog dana biti u } \\
\text { potpunosti znanstveno objašnjeni. }\end{array}$ & ,136 & ,749 & ,258 & &,- 155 \\
\hline $\begin{array}{l}\text { Nastanak života na Zemlji može se objasniti } \\
\text { jedino znanošću. }\end{array}$ & ,117 &, 723 & &,- 164 &,- 279 \\
\hline $\begin{array}{l}\text { Religija je potrebna onima koji se ne mogu } \\
\text { sami nositi sa životnim problemima. }\end{array}$ & & ,623 & ,241 &,- 361 & \\
\hline $\begin{array}{l}\text { Za bliske prijatelje/prijateljice odabirem } \\
\text { isključivo ateiste/ateistice. }\end{array}$ & & & ,865 & & \\
\hline $\begin{array}{l}\text { Jedino se dobro osjećam u društvu onih koji o } \\
\text { Bogu i vjeri misle isto što i ja. }\end{array}$ & & ,155 & ,836 & ,143 & \\
\hline Ateisti su u pravilu inteligentniji od vjernika. & ,357 & ,200 &, 584 &,- 278 &, 168 \\
\hline $\begin{array}{l}\text { Horoskop će jednog dana biti znanstveno } \\
\text { prihvaćen. }\end{array}$ & ,213 & & & ,789 & \\
\hline $\begin{array}{l}\text { Neka znanost priča što god hoće, ali ljudima } \\
\text { su neke stvari naprosto suđene. }\end{array}$ &,- 153 & & & ,668 & ,264 \\
\hline $\begin{array}{l}\text { U teškim trenucima i ja pomislim da Bog } \\
\text { možda ipak postoji. }\end{array}$ &,- 483 & ,231 & ,225 &, 537 & ,303 \\
\hline $\begin{array}{l}\text { Ne isključujem mogućnost postojanja neke } \\
\text { Više sile koja upravlja našim životima. }\end{array}$ & &,- 199 & & ,262 & ,728 \\
\hline
\end{tabular}


Ne vjerujem u Boga, ali vjerujem u postojanje

Više sile. $-, 307-, 119$ , 130 , 625

Ništa nije moguće tvrditi s apsolutnom sigurnošću pa tako ni postojanje Boga. , 248 , 621 Postotak objašnjene varijance $16,0 \% \quad 14,2 \% \quad 12,2 \% \quad 11,5 \% \quad 10,5 \%$

Ustanovljene su latentne dimenzije s opisima na temelju manifestnih varijabli koje ih saturiraju:

\section{Ateist racionalist}

Za ispitanike sklone ovom faktoru religija je skup besmislenih postavki. Oni smatraju kako religioznost čovjeku nimalo ne pomaže u rješavanju moralnih dvojbi te kako su sve svjetske religije pune logičkih nedosljednosti. Tvrdnju kako bez obzira na nevjerovanje u Boga ipak u teškim trenucima osjete potrebu da mu se obrate odbacuju, a vjernike doživljavaju kao gomilu zaslijepljenih ljudi koji uopće nemaju vlastito mišljenje. Također se ne slažu s tvrdnjom kako u teškim trenucima pomisle da Bog možda ipak postoji. Oni se donekle slažu i s tvrdnjom kako su ateisti po pravilu inteligentniji od vjernika te također odbacuju mogućnosti postojanja neke Više sile.

\section{Ateist pozitivist}

Ovaj tip ateista »odvojio« se od njemu konceptualno srodnog racionalista. Zastupnici ovog tipa slijepo vjeruju u znanost te smatraju kako je religija samo za one koji su slabi i ne mogu se sami nositi sa životnim problemima. Ispitanici skloni sadržaju ovog faktora smatraju kako će znanost jednoga dana doći do odgovora na pitanja o smislu svega postojećeg, kako će neki neobjašnjivi fenomeni jednog dana biti u potpunosti znanstveno objašnjeni te kako se nastanak života na zemlji može objasniti samo znanošću. Također su skloni prihvaćanju tvrdnje kako su sve svjetske religije pune logičkih nedosljednosti.

\section{Antireligijski orijentiran ateist ili antiteist}

Treći faktor saturiraju prvenstveno tvrdnje koje govore o preferiranju ateista kao bliskih osoba. Naime, ispitanici skloni ovom faktoru za bliske prijatelje/prijateljice odabiru isključivo ateiste/ateistice, a dobro se osjećaju samo u društvu onih koji o Bogu i vjeri misle isto što i oni. Varijabla s nešto nižom saturacijom na ovom faktoru ukazuje nam na postojanje mišljenja kako su ateisti po pravilu inteligentniji od vjernika. Kod ovih ispitanika postoji također i sklonost prihvaćanju tvrdnje kako su svi vjernici gomila zaslijepljenih ljudi koji uopće nemaju vlastito mišljenje. Napomenimo 
da su distribucije ovih tvrdnji asimetrične prema nižim vrijednostima što u stvari znači da se za ovaj tip ateizma opredjeljuje relativno manji broj ispitanika.

\section{Ateist sudbinist}

Četvrti faktor govori o postojanju posebnog tipa nereligijskog uvjerenja. Nije dakle riječ o klasičnim vjernicima, ali ni klasičnim ateistima. Ovi ispitanici nisu vjernici u smislu pripadanja nekoj konfesiji, ali pokazuju sklonost vjerovanja u horoskop i sudbinu, dakle znanosti »konkurentske« metode i koncept. Mišljenja smo da je riječ o uvjerenju koje je u osnovi ipak bliže ideji alternativnog, a ne znanstvenog objašnjenja svijeta. Budući da horoskopi i slične »metode« pretendiraju na objašnjenje i budućnosti i sadašnjosti, dakle predviđanje sudbine, riječ je ipak o vrsti uvjerenja koje jednostavno pojam Boga zamjenjuje vjerom u Usud. Stoga ćemo zastupnike ovog faktora nazvati sudbinistima. Ispitanici skloni ovom faktoru smatraju kako će horoskop jednog dana biti znanstveno prihvaćen te kako su neke stvari ljudima jednostavno suđene. Također, pokazuju sklonost da u teškim trenucima pomisle kako Bog možda ipak postoji. Ponovnim uvidom u deskriptivnu analizu tih tvrdnji zaključujemo da većina ispitanika odbacuje te tvrdnje, dakle zapravo odbacuju sudbinizam.

\section{5. Štovatelj Više sile}

Ovaj tip ispitanika konceptualno je zamišljen kao još jedna vrsta alternativno usmjerenog ateista, koji je ponešto različit od ateista sudbinista. Varijable koje saturiraju ovaj faktor govore nam o tipu ateista koji baš i ne vjeruje u Boga, točnije: nije ni sam siguran postoji li Bog jer jednostavno smatra kako ništa nije moguće tvrditi s apsolutnom sigurnošću, ali ne odbacuje mogućnost postojanja Više sile koja upravlja našim životima. Moglo bi se čak ustvrditi da je riječ o pokušaju traganja za smislom života kao posljedicom potrebe za izvjesnošću i čvrstim osloncem. Ispitanicima te provenijencije znanstvena argumentacija očito nije u dovoljnoj mjeri prihvatljiva, jer ne rješava njihove osobne probleme. Napomenimo još da distribucije frekvencija tih varijabli pokazuju blago odbacivanje, ali i blagu bimodalnost, što upućuje na činjenicu da broj izrazitih pristalica te dimenzije nije velik.

Napominjemo da naši podaci govore i u prilog postojanja tzv. »nezainteresiranog ateista«, ali su tu dimenziju saturirale samo dvije varijable (»Mene ustvari uopće ne zanimaju rasprave ni o Bogu, ni o religiji«, te »Rasprave o postojanju Boga za mene su gubitak vremena«) pa smo je zbog korektnosti isključili iz analize. 


\subsection{Tipovi ateista i neka sociodemografska i sociokulturna obilježja}

U ovom ćemo dijelu analizirati povezanost dobivenih tipova ateista sa spomenutim sociodemografskim karakteristikama, odnosno elementima religijskog identiteta. Namjera nam je ustanoviti koje od tih karakteristika na statistički značajan način opisuju psihosocijalne, odnosno sociokulturne profile dobivenih dimenzija.

Analiza je pokazala da veličina naselja iz kojeg dolaze, materijalni status njihove obitelji, godina studija (niže i više godine) te simpatizerstvo određenih političkih stranaka nije statistički značajno povezano ni s jednim od tipova ateista. Budući da niz istraživanja fenomena religioznosti pokazuje da su neke od tih karakteristika značajno povezane s religioznošću ${ }^{13}$ zaključit ćemo da se zagovornici ateizma bitno razlikuju od onih koji su religiozni. Ovaj je nalaz dobiven na svih pet tipova ateističkih uvjerenja.

Na prvoj zadržanoj dimenziji, koja se odnosi na ateista racionalista, utvrđena je statistički značajna povezanost sa sljedećim varijablama: stupanj religioznosti majke i oca, stupanj uvjerenja, odnos prema ateizmu i religijskom uvjerenju te mišljenje o postojanju Boga. Utvrđeno je da su ispitanici, koji za svoju majku ne mogu procijeniti je li ateistica ili vjernica, nešto skloniji ovoj dimenziji od onih, koji za svoju majku procjenjuju kako je vjernica ili sklonija vjerovanju u Boga $\left(F_{(2,81)}=3,836 ; p=0,026\right)$. Osim toga, ispitanici čiji je otac ateist ili skloniji nevjerovanju, u većoj su mjeri od ostalih skloni racionalističkom ateizmu $\left(F_{(2,80)}=3,838 ; p=\right.$ 0,026). Istraživanje također pokazuje da su racionalističkom ateizmu najskloniji uvjereni ateisti, odnosno ispitanici mnogo skloniji nevjerovanju, a najmanje su skloni oni, koji ne mogu procijeniti svoje uvjerenje odnosno koji su skloniji vjerovanju $\left(F_{(3,81)}=14,005 ; p<0,001\right)$. Osim toga, ovoj su dimenziji statistički značajno skloniji ispitanici koji su se izjasnili kao uvjereni protivnici religijskog uvjerenja, u odnosu na one koji nisu protivnici ni ateističkog, niti religijskog uvjerenja $\left(F_{(3,80)}=8,571 ; p<0,001\right)$. Ispitanici apsolutno sigurni u nepostojanje Boga imaju najviše rezultate na ovoj dimenziji. U usporedbi s njima znatno niži prosjek na ovoj dimenziji imaju svi ostali ispitanici $\left(F_{(2,82)}=18,009 ; p<0,001\right)$.

Zanimljiv rezultat dobili smo pri provjeri prethodno navedenih karakteristika na dimenziji ateist pozitivist. Naime, ustanovili smo da su tom tipu ateizma skloniji ispitanici čija je majka vjernica ili sklonija vjerovanju, u usporedbi s onima kojima je majka ateistica ili sklonija nevjerovanju $\left(F_{(2,81)}\right.$

\footnotetext{
${ }^{13}$ Primjerice ispitanici iz manjih naselja, odnosno nižega materijalnog statusa po pravilu su religiozniji (Nikodem, 2011).
} 
$=3,994 ; p=0,022)$. Naizgled paradoksalni rezultat moguće je objasniti svojevrsnom emancipacijom ispitanika od primarnoga majčinog socijalizacijskog utjecaja. Pri interpretaciji te dimenzije već smo spomenuli da je riječ o vjeri u znanost pa je moguće da je došlo do »kopernikanskog obrata $u$ u kome se Bog zamjenjuje znanošću. Tom su faktoru skloniji ispitanici koji su uvjereni protivnici religijskog uvjerenja, u odnosu na one koji su donekle protivnici ateizma ili su uvjereni protivnici ateizma $\left(F_{(3,80)}=2,925\right.$; $p=0,039)$.

Dimenziji koja opisuje antiteista, odnosno antireligijski orijentiranog ateista skloniji su oni koji su donekle protivnici religijskog uvjerenja od onih koji nisu protivnici ni ateističkog, niti religijskog uvjerenja $\left(F_{(3,80)}=\right.$ $4,486 ; p=0,006)$. Tom su tipu ateista manje skloni oni koji procjenjuju kako je na formiranje njihova stava prema religiji najviše utjecala obitelj, odnosno oni koji su svoje stavove prema religiji formirali sami, i to $\mathrm{u}$ odnosu na one koji procjenjuju kako je na taj stav utjecao netko drugi, primjerice prijatelji, škola, vjerska zajednica i sl. $\left(F_{(3,81)}=5,173 ; p=0,003\right)$. Iako je interpretacija te povezanosti na prvi pogled problematična, mišljenja smo da je ključni moderator u ovom opredjeljenju socijabilnost ispitanika. Takvi ispitanici, naime, imaju izrazitu potrebu za socijabilnošću, čega je pretpostavka konformiranje s grupnim uvjerenjem. Dakle, ako referentna grupa zagovara antireligijsko raspoloženje takvo će mišljenje bespogovorno prihvatiti svi njezini članovi.

Statistički značajne razlike u stupnju sklonosti dimenziji ateist sudbinist pronađene su na mnoštvu karakteristika ispitanika. Tom su tipu ateista, naime, skloniji oni čiji je otac nižeg ili srednjeg obrazovanja $\left(t_{(84)}=2,224\right.$; $p=0,029)$, a isto je utvrđeno i za njihovu majku $\left(t_{(84)}=2,013 ; p=0,047\right)$. Ovoj su dimenziji manje skloni ispitanici čiji je otac ateist ili skloniji nevjerovanju u Boga, u odnosu na one koji nisu sigurni u religioznost oca $\left(F_{(2,80)}=4,978 ; p=0,009\right)$. Na toj dimenziji po sklonosti prednjače studenti društveno-humanističkih i tehničkih fakulteta, u odnosu na studente $\mathrm{s}$ medicinskih i biotehničkih fakulteta $\left(F_{(2,80)}=2,932 ; p=0,038\right)$. Nadalje, studenti koji se izjašnjavaju kao skloniji vjerovanju ili su uvjereni da Bog postoji skloniji su dimenziji ateista sudbinista od onih koji se izjašnjavaju kao uvjereni ateisti $\left(F_{(3,81)}=4,805 ; p=0,004\right)$. Ispitanici koji nisu protivnici ni ateističkog, ni religijskog uvjerenja skloniji su ovoj dimenziji od onih koji su uvjereni ili umjereni protivnici religijskog uvjerenja $\left(F_{(3,80)}=6,850\right.$; $p<0,001)$. Ispitanici koji su skloniji mišljenju da Bog postoji ili su apsolutno sigurni da Bog postoji »viši« su na ovom faktoru od ispitanika koji su skloniji mišljenju da Bog ne postoji $\left(F_{(2,82)}=4,509 ; p=0,014\right)$. Dimenziji ateista sudbinista skloniji su ispitanici koji djelomično ili u potpunosti pri- 
hvaćaju postavke nauka Crkve od ispitanika koji se ne smatraju vjernicima $\left(F_{(2,82)}=3,243 ; p=0,044\right)$.

Zaključit ćemo da je riječ o ispitanicima koji nemaju jasno izdiferencirano mišljenje o vlastitom uvjerenju, iako imaju potrebu u nešto vjerovati, najvjerojatnije stoga što im to daje kakav-takav oslonac u životu. Budući da im klasično religijsko uvjerenje nije u potpunosti prihvatljivo, okreću se jednom od velikog broja alternativnih uvjerenja. Takva su uvjerenja po svom sadržaju i argumentaciji dovoljno općenita, da se mogu tumačiti na bilo koji od njima poželjnih načina. Ovaj relativni oslonac nije obvezujući i može se koristiti u svakoj prilici kao opravdanje uspjeha ili neuspjeha, odnosno kao racionalizacija životnih nedaća. Ta relativizacija tipa »nisam imao sreće« ili »sudbina je tako htjela« djelotvoran je mehanizam kompenzacije, pa i svojevrsna osobna psihoterapija.

Na posljednjoj dimeziji, nazvanoj štovatelj Više sile, utvrđena je statistički značajna povezanost sa spolom, potom odnosom prema nauku Crkve te mišljenjem o postojanju Boga. Ovoj su dimenziji studentice sklonije od studenata $\left(t_{(84)}=-1,991 ; p=0,050\right)$, potom ispitanici koji sumnjaju u temeljne postavke vjere ili ih tek djelomično prihvaćaju, u odnosu na one koji se ne smatraju vjernicima $\left(F_{(2,82)}=4,770 ; p=0,011\right)$. Na faktoru štovatelj Više sile statistički značajno više rezultate postižu ispitanici skloniji mišljenju da Bog postoji ili oni koji su u to apsolutno sigurni, u usporedbi s onima koji su skloniji mišljenju da Bog ne postoji $\left(F_{(82,2)}=3,646 ; p=0,030\right)$.

\subsection{Regresijska analiza tipova ateista u kontekstu političkih koncepata}

Budući da tipologija ateista predstavlja svojevrsni vrijednosno-stavovski sklop, u istraživanju smo pretpostavili da bi pristajanje uz određeni tip ateističkog uvjerenja moglo biti objašnjeno i nekim drugim stavovskim sklopovima. Naime, određeno idejno ili vjersko/ateističko uvjerenje zasigurno ima reperkusije po način gledanja na društveno ustrojstvo, odnosno na vrijednosne i političke preferencije. Stoga smo multiplom regresijskom analizom provjerili relaciju dobivenih ateističkih uvjerenja i odabira poželjnih zamišljaja društvenog ustrojstva. Pritom smo dobivene tipove ateista uzeli kao kriterijske varijable, a odgovarajuće političke stavovske strukture kao prediktore. Naša je pretpostavka bila da bismo statistički značajne povezanosti mogli verificirati na sljedećim stavovskim dimenzijama: nacionalizam, klerikalizam, multikulturalizam i europeizam.

Rezultati su pokazali da tri od pet utvrđenih tipova ateista nisu statistički značajno povezani ni s jednim od odabranih političkih koncepata. Za razliku od toga, ateist pozitivist značajno je povezan s europeizmom ( $\beta$ 
$=0,258 ; p<0,05)$, iako je postotak protumačene varijance relativno mali (približno 7\%).

Ateist sudbinist statistički je značajno sklon klerikalizmu $(\beta=0,351 ; p$ $<0,05 ; 12 \%$ zajedničke varijance), vjerojatno stoga što je sklonost sudbinizmu također vrsta uvjerenja alternativnog tipa, što rezultira odobravanjem uloge i utjecaja Crkve na aktualna politička zbivanja.

\section{Ograničenja provedene studije}

Budući da je naše istraživanje preliminarnog tipa, dobivene rezultate moŽemo shvatiti kao svojevrsnu provjeru empirijskog konstrukta koji će biti podvrgnut daljnjim provjerama. Naime, naša je interpretacija pokazala da su četiri od pet dobivenih tipova zapravo vrste uvjerenja, načelno analogna vjerskim uvjerenjima alternativnog tipa. Operacionalizaciju smo proveli na temelju nama dostupne literature, ponajprije usmjerene prema "generalnom « ateizmu, najčešće suprotstavljenom klasičnom religijskom uvjerenju. ${ }^{14} \mathrm{~S}$ obzirom na okolnosti i svrhu istraživanja, glavno ograničenje predstavlja uzorak ispitanika, jer reprezentira specifičnu populaciju, vjerojatno atipičnu za analizirani fenomen. Nadalje, poduzorak ateista relativno je mali $(\mathrm{N}=87)$, iako predstavlja odgovarajuću proporciju ispitivane populacije. Ipak, naša je osnovna ideja bila provjera sadržajne konzistentnosti pretpostavljanih tipova ateizma, što je istraživanje i pokazalo. Stoga smo mišljenja da bismo dobivenu tipologiju vjerojatno dobili i na široj populaciji. Spomenimo još da naša pretpostavka o postojanju sedam neovisnih tipova ateizma nije u potpunosti potvrđena. Naime, dvije pretpostavljene dimenzije (znanstveni ateist $i$ alternativni ateist) razdvojile su se na četiri dimenzije (racionalist $i$ pozitivist te sudbinist i štovatelj Više sile). Glavne konceptualne odrednice predviđenih dimenzija pokazale su se opravdanima, ali smo ih, zbog varijabli »dodanih« iz drugih dimenzija donekle rekonceptualizirali. Smatramo da treba još preciznije operacionalizirati čestice instrumenta (fokusirati na tip, ekstremizirati i sl.). Usporedbom empirijski verificiranih tipova ateizma s onima koji se spominju u literaturi možemo zaključiti da ateizam nije jednodimenzionalan, a broj potencijalnih tipova ostaje i dalje arbitraran. Kao što smo već napomenuli, istražiti ateizam nije moguće bez istraživanja religijskog uvjerenja, jer oba proizlaze, konotacijski gledano, iz srodnih pitanja - čovjekove potrebe da osmisli vlastitu egzistenciju u društvenom i političkom kontekstu. Zbog apriorne ograničenosti veličine teksta, u ovom smo radu propustili usporediti ateiste i vjernike na psihosocijalnoj razini,

\footnotetext{
${ }^{14}$ Kao iznimka može se spomenuti Ćimićeve pokušaje razlikovanja četiri tipa ateista i tri tipa ateizama koji načelno sliče klasifikaciji koju smo istraživanjem dobili.
} 
što bi svakako dodalo neke ključne parametre njihova razlikovanja, kao i moguću dodatnu argumentaciju nužnu za elaboriranje novoga teorijskog koncepta.

\section{Zaključak}

Istraživanje je pokazalo da je moguće govoriti o pet tipova ateista: racionalist, pozitivist, antiteist, sudbinist $i$ štovatelj Više sile.

Ateist racionalist apsolutno je siguran u nepostojanje Boga; on također smatra da je religija skup besmislenih postavki i logičkih nedosljednosti. Vjernici su zaslijepljeni ljudi, koji se - za razliku od njega - u teškim trenucima obraćaju Bogu, iako On ne postoji, kao što ne postoje Više sile i nadnaravne pojave. Riječ je o ispitanicima čiji je otac također ateist. Oni su ujedno i deklarirani ateisti te protivnici religijskog uvjerenja.

Ateist pozitivist slijepo vjeruje u znanost. On također vjeruje da će znanost jednoga dana objasniti smisao svega postojećeg. Religiozne ljude smatra slabićima koji ne primjećuju mnoštvo logičkih nedosljednosti kojima religija obiluje. Od važnijih spoznajnih tema oni ističu znanstveno objašnjenje nastanka života. Takvi su pojedinci uvjereni protivnici religijskog uvjerenja, po pravilu iz obitelji u kojima je majka vjernica ili sklonija vjerovanju.

Antireligijski orijentiran ateist ili antiteist uopće se ne bavi spoznajnim pitanjima, kao ni pitanjem smisla, nego ga ponajprije zanima osobno društveno okruženje. On se po pravilu druži s ateistima, smatrajući ih inteligentnijima od vjernika te se dobro osjeća isključivo u društvu istomišljenika, jer su za njega vjernici jednostavno gomila zaslijepljenih ljudi koji nemaju vlastito mišljenje. Po našem mišljenju poanta nije u razmatranju vjere ili vjerovanja, nego u očitom zadovoljavanju društvenih potreba koje se temelje na istomišljeništvu i pukom dihotomnom odbijanju rasprave o vjeri i nevjerovanju. $\mathrm{Na}$ formiranje njihova svjetonazora najčešće je utjecala škola ili prijatelji. Iako načelno jesu protivnici religijskog uvjerenja, njihova se isključivost ponajprije odnosi na razinu društvenih interakcija u kojima nastoje izbjeći kontakt $\mathrm{s}$ religijom i religioznim osobama jer vjeruju da je glavni kriterij bilo koje prosudbe inteligencija.

Ateist sudbinist, nije ni klasičan ateist, niti klasičan vjernik, što ponajprije znači da ne odriče postojanje nadnaravnoga, ali i da ne prihvaća objašnjenje koje nudi bilo koja od »klasičnih « i priznatih konfesija. Umjesto vjere u Boga, sklon je drugoj vrsti uvjerenja. On vjeruje u sudbinu, a objašnjenja toga što mu se događa traži u horoskopima i sličnim alternativnim izvorima objašnjenja. Sudbinist smatra da je horoskop u toj mjeri prediktibilan za živote ljudi, da će jednog dana biti čak i znanstveno 
prihvaćen. Zanimljivo je da takvi pojedinci u osobito teškim okolnostima pomisle da Bog ipak postoji. Ovi ispitanici po pravilu potječu iz obitelji u kojima su otac i majka nižeg obrazovanja. Indikativno je također da u obitelji ne postoji jasno religijsko opredjeljenje što može značiti da je kod takvih pojedinaca izostala vjerska edukacija i socijalizacija. Takvi pojedinci najčešće studiraju tehničke i društveno-humanističke znanosti, što u najmanju ruku znači da nije riječ o homogenom dijelu studentske populacije, nego prije o popriličnoj šarolikosti zastupnika tog uvjerenja. Valja na kraju napomenuti da zastupnici te dimenzije nisu baš posve neskloni vjerovanju u Boga i nauk Crkve, nego prije to da im horoskop i slična "pomagala« služe kao svojevrsna pragmatička »nadopuna«.

Za razliku od sudbinista, koji nema potrebe personificirati predmet svoga uvjerenja, već samo ime štovatelj Više sile upućuje na potrebu konkretnijeg zamišljaja Uzročnika svega postojećeg, odnosno Svrhe (smisla života). Riječ je o nešto konkretnijem traženju životnog oslonca, pa i kriterija za prosudbu svojih i tuđih djela. Takva osoba spoznajni je relativist, a ne vjernik klasičnog tipa. Poanta ovog opredjeljenja jest vjera u postojanje Više sile, svrhe i univerzalnog smisla života. Ovom su tipu uvjerenja studentice sklonije od studenata te ispitanici skloni sumnji u temeljne postavke bilo kojega klasičnog religijskog uvjerenja, iako su skloni generalnoj ideji da Bog možda ipak postoji.

Može se primijetiti da smo u ovom odjeljku, ne baš posve slučajno, u četiri od pet dobivenih tipova istaknuli da je riječ o vjerovanju kao ključnom kriteriju prosudbe $u$ odgovorima na fundamentalna pitanja, kao što su traganje za smislom života, objašnjenje svega postojećeg, položaja čovjeka u univerzumu i sl. Mišljenja smo da je u tim slučajevima doista riječ o uvjerenju koje se na različite načine imperativno brani te se po tome nimalo ne razlikuje od bilo kojega religijskog uvjerenja.

Jedini od dobivenih tipova koji tu potrebu smatra nevažnom i rukovodi se racionalnom interpretacijom poznate sentencije Credo quia absurdum jest prvi od naših dobivenih tipova, dakle ateist racionalist. Zaključit ćemo da se četiri od pet dobivenih tipova ateista oslanjaju na osobno uvjerenje, odnosno potrebu da sebe odrede ateistom, ali je njihov ateizam zapravo zamjenska religija kojom uglavnom rješavaju neke svoje ili neke grupne, odnosno općenito društvene probleme vjerojatno stoga što su oni zapravo vjernici koji to nisu osvijestili, odnosno koji to ne žele priznati.

Na samom kraju, jedan se citat Nikole Dugandžije čini izrazito prikladnim: »Niti razlikovanje teizma i ateizma, plodno u određenom trenutku, ne može ostati duže zadovoljavajuće, ukoliko ne predvidi mnoštvo naizgled neprimjetnih prelaza, koji osjenčavaju i jednu i drugu pojavu, pokazujući da 
između njih postoji niz podudarnosti i trajna veza, makar i toliko nejasna da ponešto uvijek ostaje tajnom, ali i dovoljno prisutna da se primijeti kako proučavanje ne treba završavati prije vremena« (Dugandžija, 1993: 72).

\section{LITERATURA}

Aničić, Miljenko (2007). »Nacionalizam u svjetlu socijalnog nauka Crkve«, Crkva u svijetu, 42 (2): 260-284.

Anić, Vladimir (2007). Rječnik hrvatskoga jezika. Zagreb: Novi Liber.

Cline, Austin (2009). Basics about Atheism \& Agnosticism: What They Are and Are Not. http://atheism.about.com/od/aboutatheism/u/AtheismBasics.htm (21. 09. 2009.).

Črpić, Gordan i Kušar, Stjepan (1998). »Neki aspekti religioznosti u Hrvatskoj«, Bogoslovska smotra, 68 (4): 513-563.

Čulig, Benjamin (2004). »Analiza političkih stavova stanovništva Hrvatske«, Socijalna ekologija, 13 (3-4): 287-304.

Ćimić, Esad (1984). Drama ateizacije. Beograd: Mladost.

Dawkins, Richard (2007). Iluzija o Bogu. Zagreb: Izvori.

Dugandžija, Nikola (1993). »Između teizma i ateizma.«, u: Štefica Bahtijarević (ur.). Prilozi izučavanju nereligioznosti i ateizma 2. Zagreb: IDIS, pp. 71-85.

Dugandžija, Nikola (1994). Ateizam. Zagreb: Školske novine.

Edwards, Paul (ur.) (1967). The Encyclopedia of Philosophy. New York: Macmillan i Free Press.

Filipović, Vladimir (ur.) (1965). Filozofijski rječnik. Zagreb: Matica hrvatska.

Gorlow, Leon i Schroeder, Harold E. (1968). »Motives for Participating in the Religious Experience«, Journal for the Scientific Study of Religion, 7 (2): 241-251.

Jukić, Jakov (1991). Budućnost religije: sveto u vremenu svjetovnosti. Split: Matica hrvatska.

Klasnić, Ksenija (2007). Neki psihosocijalni aspekti tipova religioznosti. Diplomski rad. Zagreb: Filozofski fakultet.

Lažnjka, Jasminka (1995). »Tradicionalna i nova religioznost u postkomunizmu: promjene u religioznosti studenata 1990.-1994.«, Društvena istraživanja, 6 (1): 49-70.

Maldini, Pero (2006). »Obnovljena religioznosti i demokratizacija hrvatskog društva«, Društvena istraživanja, 15 (6): 1105-1125.

Marinović Jerolimov, Dinka (1993). »Nereligioznost u Hrvatskoj 1968-1990«, u: Štefica Bahtijarević (ur.). Prilozi izučavanju nereligioznosti i ateizma 2. Zagreb: IDIS, pp. 87-136.

Marinović Jerolimov, Dinka (1999). »Religijske promjene u Hrvatskoj od 1989. do 1996. godine«, u: Ivan Grubišić i Siniša Zrinščak (ur.). Religija i integracija. Zagreb: Institut društvenih znanosti Ivo Pilar, pp. 187-203.

Marinović Jerolimov, Dinka (2005). »Tradicionalna religioznost u Hrvatskoj 2004.: između kolektivnoga i individualnoga«, Sociologija sela, 43 (2): 303-338. 
McGrath, Alister (2004). The Twilight of Atheism: The Rise and Fall of Disbelief in the Modern World. New York: Doubleday.

Mesić, Milan (2006). Multikulturalizam: društveni i teorijski izazovi. Zagreb: Školska knjiga.

Molnar, Thomas (1980). Theists and Atheists: A Typology of Non-Belief. The Hague: Mouton Publishers.

Nikodem, Krunoslav (2011). »Religija i crkva: pitanja institucionalne religioznosti u suvremenom hrvatkom društvu«, Socijalna ekologija, 20 (1): 5-30.

Plačko, Ljudevit (1993). »Suvremeni ateizam«, u: Štefica Bahtijarević (ur.). Prilozi izučavanju nereligioznosti i ateizma 2. Zagreb: IDIS, pp. 23-36.

Routledge Encyclopedia of Philosophy (1998). Version 1.0. London and New York: Routledge.

Smith, George H. (1989). Atheism: The Case against God. New York: Prometheus Books.

Zrinščak, Siniša (1993). »Sociologija religije i sustavni ateizam«, u: Štefica Bahtijarević (ur.). Prilozi izučavanju nereligioznosti i ateizma 2. Zagreb: IDIS, pp. 57-69.

Zrinščak, Siniša (2001). »Ima neka tajna veza: religioznost mladih kao indikator društvenih i religijskih promjena«, Društvena istraživanja, 10 (1-2): 19-40.

\title{
Empirical Verification of a Typology of Atheism
}

\author{
Benjamin ČULIG, Ksenija KLASNIĆ \\ Department of Sociology, Faculty of Humanities and Social Sciences, University \\ of Zagreb, Croatia \\ bculig@ffzg.hr,kklasnic@ffzg.hr \\ Jelena JAKŠIĆ \\ Zagreb, Croatia
}

Starting from the assumption that atheism as a personal conviction - in a similar way to religious belief - may appear in different forms, the basic aim of this paper was to verify the hypothesis on the existence of 7 different types of atheists, which resulted with preliminary scientific survey research conducted in 2008th on a stratified proportional quota sample $(\mathrm{N}=353)$ of students at the University of Zagreb. The research has shown that it is possible to talk about 5 types of atheists: rational type, positivistic type, anti-theist type, fatalist type and admirer of force majeure. The rational type is absolutely convinced in the absence of God and believes that religion is a set of meaningless settings and logical inconsistencies. The positivistic type blindly believes in science. He/she also believes that science will one day explain the meaning of all existing. The anti-religious oriented atheist or anti-theist type is not even interested in cognitive issues, or in questions of meaning; instead, he/she is primarily interested in the personal so- 
cial environment. This type usually spends time with atheists, considering them more intelligent than believers. The fatalist type is neither a classic atheist nor a believer. Instead of faith in God, this type is prone to another kind of belief. $\mathrm{He} / \mathrm{she}$ believes in fate and he/she looks for answers in horoscopes and similar sources of alternative explanations of his/her own life and the lives of people around him. The admirer of force majeure is a cognitive relativist, a believer in the existence of force majeure. The only type determined in the research which is considered to be a "real" atheist is - the rational atheist. All others are merely different types of alternative believers.

Key words: atheism, types of atheists, rational atheist, positivistic atheist, antitheist, atheist fatalist, atheist admirer of force majeure 